\title{
Stagpression: The Economic and Financial Impact of the COVID-19 Pandemic
}

\author{
Mario Arturo Ruiz Estrada', Evangelos Koutronas², Minsoo Lee ${ }^{3}$
}

ABSTRACT

\begin{abstract}
This paper formulates an analytical framework to understand the spatiotemporal patterns of epidemic disease occurrence, its relevance, and implications to financial markets activity. The paper suggests a paradigm shift: a new multi-dimensional geometric approach to capture all symmetrical and asymmetrical strategic graphical movement. Furthermore, it introduces the concept of stagpression, a new economic phenomenon to explain the uncharted territory the world economies and financial markets are getting into. The Massive Pandemic Contagious Diseases Damage on Stock Markets Simulator ( $\varphi$-Simulator) to evaluate the determinants of capital markets behavior in the presence of an infectious disease outbreak. The model investigates the impact of COVID-19 on the performance of ten stock markets, including S\&P 500, TWSE, Shanghai Stock Exchange, Nikkei 225, DAX, Hang Seng, U.K.-FTSE, KRX, SGX, and Malaysia-FTSE
\end{abstract}

KEY WORDS: $\quad$ Stagpression, pandemics, economic modeling, economic desgrowth, policy modeling, stock market, COVID-19.

JEL Classification: R11, R12.

'Social Security Research Centre (SSRC), Centre for Poverty and Development Studies (CPDS), Faculty of Economics and Administration (FEA), University of Malaya (UM), University of Economics and Human Sciences in Warsaw

2Department of Mathematics, Eberly College of Arts and Science, West Virginia University

${ }^{3}$ Principal Economist, Asian Development Bank (ADB)

\section{Introduction}

The world is on the verge of an unprecedented pandemic disease, as many cities across the globe go on lockdown in response to the spread of novel coronavirus, the so-called COVID-19. The consensus among economists about the global economic shutdown due to disease pandemic is believed to be the primary determinant of stock market volatility that could lead to the biggest stock market crash in the 21 st century ${ }^{1}$. Historically, only two broadly similar episodes the Black Death of 1347 to 1351 and the Spanish Flu of 1918 to 1919. Recent events appeared to have adverse consistent, considerable, widespread short-term severe financial disruptions and medium-term consequences for economic growth and development.

Indeed, it is estimated that the SARS outbreak

Correspondence concerning this article should be addressed to: Mario Arturo Ruiz Estrada, University of Malaya (UM), Kuala Lumpur 50603, Malaysia.E-mail: marioruiz@um.edu.my caused more than 50 billion dollars of damage to the global economy (Candeias \& Morhard, 2018), which knocked off an estimated 1 percent or more from China's growth rate (Johnson \& Palmer, 2020). In parallel, the MERS outbreak caused irreparable damage in South Korea's tourist industry, translating into 2.6 billion dollars in losses (Joo et al., 2019). Furthermore, empirical evidence on seasonal epidemics such as influenza, dengue virus (DENV), zika virus (ZIKV), and Ebola virus (EBOV) also have a considerable economic impact in the affected areas. In the United States, the annual economic costs of influenza varied from 13.9 thousand dollars to 957.5 million dollars across U.S. counties, with a median of 2.47 million dollars (Liang et al., 2012). In the case of dengue fever, the overall annual cost in 2013 amounted approximately up to 8.9 billion dollars spread in 141 countries (Shepard et al., 2016). The recent zika outbreak caused socio-economic costs of approximately US\$7-18 billion in Latin America and the Caribbean from 2015 to 2017 (United Nations, 
2017). Finally, the most severe epidemic of Ebola, an estimated \$2.2 billion was lost in 2015 in the gross domestic product (GDP) of Guinea, Liberia, and Sierra Leone (Centers for Disease Control and Prevention [CDC], 2020).

Chinese authorities implemented social distancing policies to minimize the transmission of infectious disease, enforcing widespread restrictions on labor mobility and travel effective immediately after the Lunar New year holiday period. The synchronized shutdown of the factory production lines implies sharp cutbacks and sizeable output contraction with imminent repercussions on economic activity. According to the National Bureau of Statistics, microeconomic indicators exhibit a sharp decline in January and February: industrial output (-13.4 percent); fixed-asset investment (-25 percent); unemployment (+6.3 percent); and retail sales $(-20.5$ percent) (L. He, 2020). In the latter category, there were sharp declines in durable consumption: automobiles (-37 percent), clothing (-30.9 percent), jewelry (-41.1 percent), home appliances (-30.0 percent), furniture (-33.5 percent), and building materials (-30.5 percent) (Kalish, 2020). The Chinese CPI in January rose by 5.4 percent, the highest monthly rate since October 2011, while the manufacturing PMI hit a three-month low of 50 percent. The fact that inflation is rising when it fell in 2003 during the Severe Acute Respiratory Syndrome (SARS) outbreak is because this time, both supply and demand are falling but supply is falling faster (C. He, 2020). Recent estimates show that the gross domestic product will contract 10 to 11 percent in the first quarter (Cheng, 2020).

In the financial market context, the impact of COVID-19 is depicted the first two months of 2020. Capital markets materialized the increased uncertainty regarding given a new pandemic by leading to the financial market volatility of Shanghai (-10\%), Shenzhen (-6\%), and Hong Kong (-19\%) are down by comparatively modest percentages this year (Karlgaard, 2020). Energy, retailing, and transportation industries experienced substantial losses, whereas healthcare followed an opposed path (Ramelli \& Wagner, 2020). In response to the coming economy's shock, the central bank of China announced a stimulating package of 1.2 trillion yuan
( $\$ 174$ billion) to support the economy and the financial system in early February, while it has lowered benchmark lending rates in an attempt to stimulate business and investment activity (Wu, 2020).

Beyond the public health impacts of regional or global emerging and lay wider socio-economic consequences that are often not considered in risk or impact assessments. Endemic infectious diseases set in motion a complex chain of events in the economy. Outbreak and epidemics are rare and extreme events, highly diverse and volatile over time and across geographical space. Estimating epidemic and pandemic risk depends upon several factors that varied by the type of activity. The idiosyncratic nature of endemic infectious diseases is based, among others, on the magnitude and duration of the event, the size and state of the local economy, the geographical locations affected, the population density, and the period it occurs. The calculation of direct medical and hospitalization costs attributable to endemic infectious disease treatment is readily traceable. On the other hand, the estimation of the indirect costs on trade, economic development, human movement, and cultural exchange can be an onerous task.

This paper formulates an analytical framework to understand the spatiotemporal patterns of epidemic disease occurrence, its relevance, and implications to financial markets activity. The paper suggests a paradigm shift: a new multi-dimensional geometric approach to capture all symmetrical and asymmetrical strategic graphical movements in real space and time (Ruiz Estrada et al., 2016). The Massive Pandemic Contagious Diseases Damage on Stock Markets Simulator ( $\varphi$-Simulator) to evaluate the determinants of capital markets behavior in the presence of an infectious disease outbreak. The $\varphi$-Simulator investigates the complicated structures of agent interactions based on econographicological ${ }^{2}$ (Ruiz Estrada, 2017) graphical geometric approach within a framework of a Dynamic Imbalanced State ${ }^{3}$ (Ruiz Estrada, 2011) and the Omnia Mobilis ${ }^{4}$ assumption (Ruiz Estrada \& Yap, 2013). The model investigates the impact of COVID-19 on the performance of ten stock markets, including S\&P 500, TWSE, Shanghai Stock Exchange, Nikkei 225, DAX, Hang Seng, U.K.FTSE, KRX, SGX, and Malaysia-FTSE.

The paper is organized as follows. The first sec- 


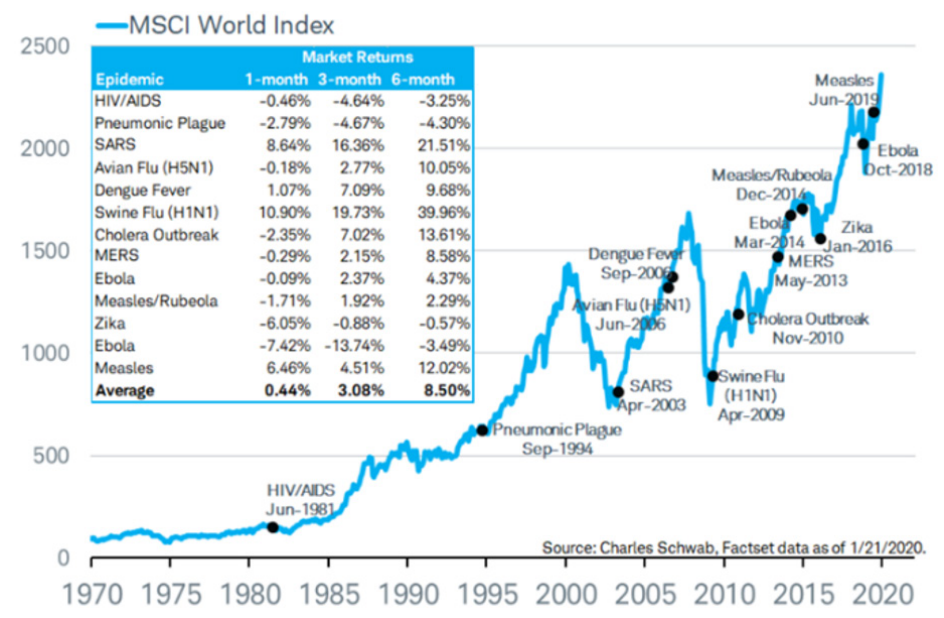

Figure 1. Historical MSCI World Index and S\&P performance under epidemic risk. Source: DeCambre, 2020

Table 1. Historical MSCI World Index and S\&P Performance Under Epidemic Risk.

\section{Epidemic}

HIV/AIDS

Pneumonic plague

SARS

Avian flu

Dengue fever

Cholera

MERS

Ebola

Measles/Rubeola

Zika

Measles/Rubeola
Month End

$6 / 1 / 1981$

9/1/1994

$4 / 1 / 2003$

$6 / 1 / 2006$

$9 / 1 / 2006$

$11 / 1 / 2010$

$5 / 1 / 2013$

$3 / 1 / 2014$

$12 / 1 / 2014$

$1 / 1 / 2016$

$6 / 1 / 2019$
$-0.3$

8.2

11.66

18.36

6.36

13.95

10.74

17.96

5.34

10.44

0.2

$-0.73$

12.03

17.45

9.82

N/A 
tion offers an overview of the financial contagion. The second section introduces the model. The third section sets a simulation for the COVID-19 impact on the financial markets. The final section summarizes the conclusions and provides policy recommendations.

\section{Literature Review}

Notwithstanding the extensive empirical literature on the propagation of financial contagion, there is no empirical study related to epidemic risk. Plausibly, unforeseen and rare events that are subject to market-wide systematic risk will influence investor behavior. The Mexican Peso crisis of 1994, the Thailand Baht crisis of 1997, the Russian Ruble crisis of 1998, the United States' subprime mortgage crisis of 2007, and the Greek debt crisis of 2010 effectuate the most notable paradigms of country-specific crises. Based on arbitrary assumptions and self-fulfilling beliefs, the aggregate macroeconomic behavior of firms, banks, and financial institutions set off a chain of reactions that triggered international capital flow reversals. As a result, financial disturbances extended across neighboring countries, or even regions, adversely affecting the macroeconomic fundamentals, jumping to multiple equilibria ${ }^{5}$. Historically, the capital market reaction on epidemic infectious diseases tend to be short-termed (DeCambre, 2020).

151 empirical studies investigated financial market contagion, covering the period from 1990-2015 (Seth \& Panda, 2018). The extensive literature views the financial contagion phenomenon from qualitative and quantitative angles. The list is endless; we present the most known studies in the field. Several studies concentrated on understanding the underlying fundamentals of the economy and or the market at the epicenter of crisis (Dorra \& Achraf, 2014; Flavin \& Sheeman, 2015; Roy \& Roy, 2015). Alternative strands of literature consider the timeline of events to investigate the micro- and macroeconomic behavior in the short-run (Billio \& Pelizzon, 2003; Pan et al. , 2015) and longrun (Calvo \& Reinhart, 1996; Eichengreen et al., 1994). Other studies concentrated on the analysis of the event per se: the Mexican crisis of 1994 (Bannier, 2006; Bodart \& Candelon, 2009; Mighri \& Mansouri, 2014); the Asian financial crisis of 1997-1998 (Cho \& Parhizgari, 2008; Ito \& Hashomoto, 2005; C. Wu et al., ; the Russian crisis of 1998 (Rigobon, 2003; Saleem, 2009; Sojli,
2007; Steinherr, 2006), and; the global financial crisis of 2008 (Kenourgios \& Dimitriou, 2015; Kim, Kim, \& Lee, 2015; Luchtenberg \& Vu, 2015); Greek debt crisis of 2010 (Arghyrou \& Kontonikas, 2012; Chira \& Marciniak, 2014; Constancio, 2012; Mink \& De Haan, 2013).

In the quantitative context, empirical studies employed numerous econometric techniques: Co-skewness, Co-volatility and Co-kurtosis (Fry-McKibbin \& Hsiao, 2015; Hsiao \& Morley, 2015; Tabak, de Castro Miranda, \& da Silva Medeiros, 2016); regression analysis (Caporin et al., 2018; Dooley \& Hutchison, 2009; Glover \& Richards-Shubik, 2014; Mondria \& C., 2013); Generalized Auto-Regressive Conditional Heteroskedasticity (GARCH) (Abbara \& Zevallos, 2014; Hoesli \& Reka, 2013; Jayech, 2016); Granger causality (Bekiros, 2014; Gomez-Puig \& Sosvilla-Rivero, 2016; Islam, 2014; Mollah et al., 2016); Markov switching models (Dimitriou \& Simos, 2013; Flavin \& Sheeman, 2015; Guo et al., 2011; Rotta \& Pereira, 2015), and; VAR analysis (Flavin \& Sheeman, 2015; Kilic \& Ulusoy, 2015; Mollah et al., 2016; Roy \& Roy, 2015; Samarakoon, 2011).

\section{The Model}

Consider a multi-dimensional interlinked coordinate space obtained by multiplying the $n$-spaces of the $n$ players. The construction of the inter-linkage coordinate space is based on Ruiz Estrada's (2016) Econographicology framework. Each dimension has an n-dimension state vector that contains the effect of prior strategic interactions relative to that dimension. $\mathrm{N}$-dimensional equilibrium points depict the symmetric and asymmetric virus behavior that occurs at the same time and space. The projection of $\mathrm{N}$-dimensional state vectors in a multidimensional Euclidean n-sphere manifold embeds in the Euclidean (n+1)-plane. The multi-dimensional representation of endogenous and exogenous variables depicts the entire simultaneous strategic interaction of stock market performance within differential formations in space and time mapping, of which a two-dimensional Euclidean plane fails to capture (see Figure 2)(Ruiz Estrada, 2009b).

The inter-linkage coordinate space is formed by " $n$ " number of general axes (market daily behavior: ŸWuhan), of which consists of " $n$ " number of sub-spaces (stock markets: S1, S2, S3, S4, S5, S6, S7, S8, S9, S10). Time zero is considered the day where an infectious disease appeared in a population for the first time, whereas 


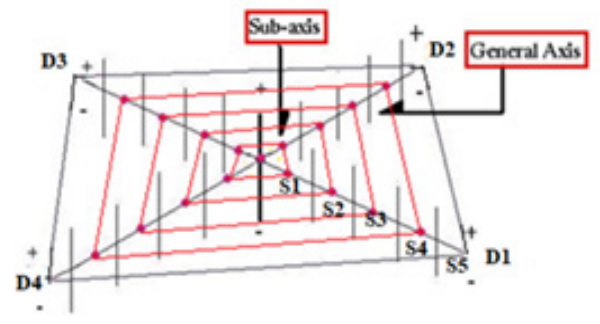

Figure 2. $-\varphi$ - Simulator coordinate system.

the terminal time is considered as the day where the epidemic is under control. The crossover point is equal to zero, which is the epicenter of the coordinated system. Each general space (axis) is divided into three sections, followed by positive integers and negative integers. The inter-linkage coordinate space allows the allocation of any value on its coordinate system based on the plot value on its sub-space (sub-axis). All general spaces start from general space 0 and take values in $[0, \infty]$. The graphical value representation takes place in the same general space. There are as many layers as there are dimensions; the links between nodes within each layer are simply all the links for a given dimension. The chain of all values through strait lines generates a single large manifold into the same graphical space and time. All the sub-axes (stock markets) are interconnected by straight lines to the end of each general axis (D) by the application of the inter-liking sub-axis system “t㧊”. The connection of all general axes and sub-axes stock markets in the same level of analysis until we arrive at the last sub-axis called the global average stock market performance index $(\overline{\mathrm{G}})$. $\overline{\mathrm{G}}$ is estimated by expression 1. Each sub-axis (stock market) performance (maximum/minimum) is calculated by the partial differentiation from $\left(\frac{\partial \ddot{\mathrm{Y}}_{i, j}}{\partial s_{i, j}}\right)$ to $\left(\frac{\partial^{2} \ddot{Y}_{i, j}}{\partial 2 s_{i, j}}\right)$ in real-time
(姲) (see Expression 2 and 3) (Ruiz Estrada, 2009a).

$\bar{G}_{i}=\log \left\{\frac{\left[\phi\left(\frac{\partial \dot{Y}_{i, j}}{\partial s_{i, j}}\right)+\cdots+\phi\left(\frac{\partial \vec{Y}_{i, n}}{\partial s_{i: n}}\right)\right]}{n}\right\}$

where $\Delta \ddot{Y}_{i: j}$ corresponds to the infectious disease daily growth rate. Differentiation of expression (1) will give the maximum or minimum

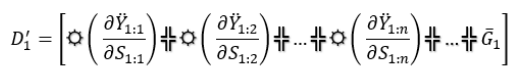

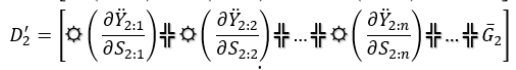

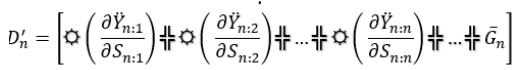

The second differentiation of expression (2) determines the critical point (inflection point)

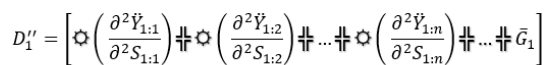

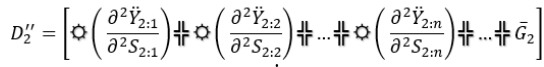

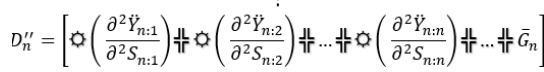

All distributed functions in different micro-spaces under different general-space and sub-space levels apply the Omnia Mobilis, "Everything is moving," 
assumption. This assumption allows a large number of variables to be simultaneously observed in our multi-dimensional analysis, as opposed to the Ceteris Paribus assumption, which keeps variables constant.

Partial differentiation generates asymmetric fluctuations of different periodicity in the form of waves. These waves affect all sectors in the economy, causing a smash effect (Ruiz Estrada, 2013). Whereas the Kondratieff wave theory (Kondratieff, 1922; Schumpeter, 1954) identifies the phases of business cycle - expansion, peak, contraction, trough, and recovery, smash effect identifies financial and economic crises because of improbable, unpredictable events such as earthquakes, floods, droughts, epidemics or terrorist incidents. In parallel, the Black Swan theory (Taleb, 2007) situates natural and human-made events in a historical and theoretical context to categorize event patterns and pinpoint early warning signs so that a realistic preevent assessment can be prepared. Notwithstanding theory's wide acceptance among finance professionals, it provides a limited understanding of the social, economic, cultural, and environmental impacts of unexpected events on capital markets due to lack of scientific rigor.

The socio-economic landscape is subject to endogenous and exogenous uncertainties. In principle, these drivers of change may retain their essential properties; however, their impact on financial markets has changed. The new complex environment emerged unknown systematic risks (regulatory/legislative changes, political uncertainty, environmental scarcity, climate change, regional conflicts, and cybercrime) and unique needs (social protection, food and water security, increased poverty). These conditions require a dynamic assessment framework, which requires to suggest policies that promote adaptation and resiliency rather than a philosophy of control.

\section{The Application of the- $\varphi$-Simulator on Ten Major Stock Markets}

$\varphi$-Simulator conceptualizes the time of evolution of epidemic mathematically and shapes the interaction between the rate of spread of infectious disease and the capital markets environment. The proposed analytical framework assumes that all capital markets are subject to epidemic risk. Each infectious disease phenomenon is independent in terms of vulnerability, frequency, intensity, magnitude, and economic impact on capital market performance. $\varphi$-Simulator attempts to quantify the risk and the probability of epidemic events, conceptualizing micro-foundations, and satisfy all a priori conditions and constraints. The dynamic imbalanced state environment constitutes an ex-ante epidemic assessment and monitoring burdensome. Nevertheless, an ex-post evaluation of epidemic damages via time series analysis is possible.

The model employs qualitative and quantitative data from Asian the Chinese Ministry of Health. We employed secondary data from ten major worldwide stock market exchanges: United States (S1 = S\&P 500); Taiwan (S2 = TWSE); China (S3 = Shanghai Stock Exchange); Japan (S4 = Nikkei 225); Germany (S5 = DAX); Hong Kong (S6 = Hang Seng); U.K. (S7 = FTSE); South Korea (S8 = KRX); Singapore (S9 = SGX); and Malaysia (S10 = FTSE Bursa). The simulation scenarios consider an epidemic period of 150 days. The model algorithm consists of 85 main variables and 1,200 sub-variables. Authors run 650 random and fuzzy simulations based on different contagion and mortality risk scenarios across China. They identified the drivers of the potential magnitude of the disease outbreak given the current 150day data availability (December 15th - March 15th) of the COVID-19 coronavirus along with the stock markets daily performance for the same period and the extended Chinese government's coronaviruses database (1995-2019). All equations in this model were transformed into a large algorithm by using Mathematica Wolfram version 11 language programming that allows authors to generate a large pool of possible results to the problem at hand.

Model preliminary findings on the global average stock market performance are summarized in Figure 3. Although the onset of symptoms was epidemiologically identified in Wuhan city on December 8th, Chinese Health officials informed the WHO (World Health Organisation) on December 31st about a cluster of 41 patients with mysterious pneumonia. There is a significant time lag between the first virus symptoms and the confirmed cases officially reported by Chinese authorities. The incubation period of the virus may appear in as few as 2 days or as long as 14 (WHO: 2-10 days; China's 


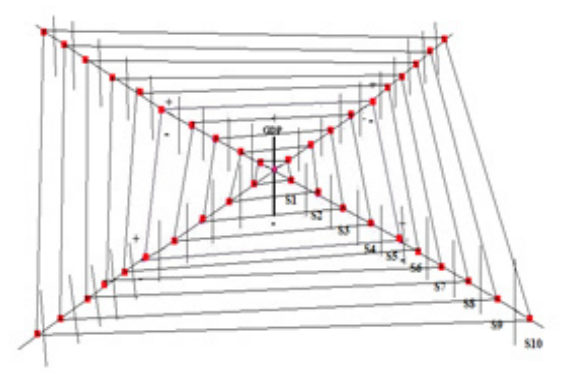

Figure 3. The Economic Smash effect from COVID-19.

National Health Commission (NHC): 2-14 days; The United States' Centers for Disease Control and Prevention (CDC) and 10-14 days), during which the virus is contagious, but the patient does not display any symptom. Recent studies report an extended incubation period of up to 28 days (Lauer et al., 2020). Given the high population density and distribution, it is plausible to argue that epidemics extended beyond the geographical boundaries of Hubei Province. Besides, virus acceleration spread rate and intensity are higher than those of Severe Acute Respiratory Syndrome (SARS) (Ruiz Estrada \& Koutronas, 2020).

All estimates are based on confirmed infected cases who developed symptoms, making no inferences about the role of asymptomatic infection in virus transmission dynamics. Asymptomatic transmission epicheirema has been subject to skepticism among epidemiologists . Nevertheless, the asymptomatic transmission can explain to a great extent why coronavirus outbreak overwhelmed countries like Italy, the United States, and Spain. In spite of the Draconian measures of social distancing, countries' epidemic forecasting was based on false assumptions on virus transmission and incubation period, leading to underestimated projections about the epidemic trajectories.
Furthermore, COVID-19 projections were based on China's official confirmed COVID-19 incidents, of which asymptomatic cases are excluded. Most important, the tracking criteria for infectious incidents have been updated several times by the Chinese officials since the beginning of the outbreak, leaving the classified confirmed cases paradoxically unchanged. These kinds of practices are inconsistent with the WHO's guidance, indicating that epidemiological models developed to estimate the spread of COVID-19 rely on skewed data (Xie, 2020). Indeed, distinct epidemiologists mentioned five underlying reasons why China's official COVID-19 data seem contradictory: assumptions about China's forthrightness; the challenges of treating the new virus in rapidly changing conditions; the limitation of predictive models; time differences in overlapping reports; and the uncertainly of implications (Sherman, 2020).

$\varphi$-Simulator assesses mild, moderate, and asymptomatic infection as part of the infected population. This assumption brings significant qualitative differences in the time-evolution of the epidemic, capturing the ground zero sub-exponential growth dynamics. Day-1 of the pandemic is considered the December 27th, 2019 (the first official reported cases). On Day-1 ( $\Delta \ddot{Y}$ Wuhan $=0.01)(\overline{\mathrm{G}} 1=1.88)$, estimates indicate a negative cor- 
relation between the initial state of the epidemic and the stock market performance index $(\overline{\mathrm{G}})$.

On Day-10 $(\Delta \ddot{Y}$ Wuhan $=0.10)(\overline{\mathrm{G}} 10=1.62)$, coronavirus spread quickly across China. Domestic capital markets (S3 = Shanghai Stock Exchange); (S6 = Hong Kong Hang Seng) continued their downward trend started on December 15th and 17th, respectively. Chinese authorities shut down Huanan Seafood Wholesale Market, but they decided to quarantine the infected areas in the Chinese New Year's holiday. Chinese New Year week-long vacation motivated some companies to increase their inventory coverage by another week. So, for most companies, the inventory coverage they have will allow them to match their supplies with demand, with no additional supply, for between two to five weeks, depending on the company's supply chain strategy. Supply lead times will also have an impact. Shipping by sea to either the United States or Europe takes, on average, 30 days. It implies that if Chinese plants stopped manufacturing prior to the beginning of the Chinese holiday on January 25th, the last of their shipments would be arriving in the last week of February.

In Day-30 ( $\Delta \ddot{Y}$ Wuhan $=0.25)(\overline{\mathrm{G}} 30=1.27)$, manufacturing lockdown due to social distancing measures has a direct effect on production activity. According to China Beige Book's flash survey, 31 percent of the firms suspend their operations, and those who reopened coping with raw materials supply shortage: 40 to 50 percent of the truck fleet remains idle (Lloyd, 2020). The coming supply-shock and trade irregularities in the first quarter fueled expectations of an economic contraction, of which interpreted to excess volatility in the domestic capital markets. The trade deal between the United States and China strengthened temporarily investor sentiment mid-January, followed by market corrections. In the regional context, Asian stock markets fell rapidly as rampant volatility takes hold: Taiwan (S2 = TWSE); Japan (S4 = Nikkei 225); South Korea (S8 = KRX); Singapore (S9 = SGX), and; Malaysia (S10 = FTSE Bursa). Taiwan Stock Exchange underperformed by a modest margin due to the fact the Taiwanese government had successfully controlled COVID-19. In contrast, the Nikkei Stock Average index has plunged, which experienced a further decline after the announcement from the Olympic Committee that the Tokyo 2020 Olympic Games will be postponed by up to a year. South Korea, along with Singapore and Malaysia, lagged as the prospect of weaker global growth due closely linked to China in global supply chains. The peripheral economies in Southeast Asia are heavily dependent on travel and tourism and are expected to be impacted by reduced visitors from China.

In Day-60 $(\Delta \ddot{Y}$ Wuhan $=0.45)(\overline{\mathrm{G}} 1=1.10)$, coronavirus crossed the Chinese borders. Singaporean and Malaysian governments announced a 4.5 billion-dollar and a 20 billion-ringgit fiscal stimulus packages, respectively. S\&P 500 had been experiencing a market correction, erasing the profits of the trade deal between the United States and China. The economic consequences of the pandemic are becoming obvious in the American economy. The unemployment rate remains at a 50-year low of 3.5 percent, but in the last two weeks of the month, almost 10 million people applied for unemployment benefits. With COVID-19 accelerating throughout the country, investor sentiment has been fueled by uncertainty about the economic consequences of getting the pandemic under control, which was translated into excess market volatility. The Federal Reserve announced a benchmark rate cut by one percent and an injection into the financial markets of 1.5 trillion dollars in the form of treasury and mortgage-backed securities. At the end of the month, the overall picture shifted when Trump administration announced an initial 2.2 trillion-dollar economic recovery package to be distributed to millions of American citizens in the form of cash backs, loans, grants, and tax breaks for businesses.

In Europe, there have been rapidly growing numbers of severe and fatal cases in many EU/EEA countries, and several countries in Europe have already reported nationwide community transmission. Italy, Spain, France, and the Netherlands have already registered healthcare system saturation due to very high patient loads requiring intensive care. Stock markets have plummeted: France, -17.21 percent; Germany, -16.44 percent; the United Kingdom, -13.74 percent and; Italy, -22.85 percent. The European Central Bank announced to inject 780 billion euros into financial markets and refinancing options for the private sector of 3 trillion euros. In the United Kingdom, the Bank of England proceeded to interest rate cuts, whereas the government announced expansionary measures of 30 billion pounds. Germany will launch a stimulus package of 750 billion euros to support the local economy. 


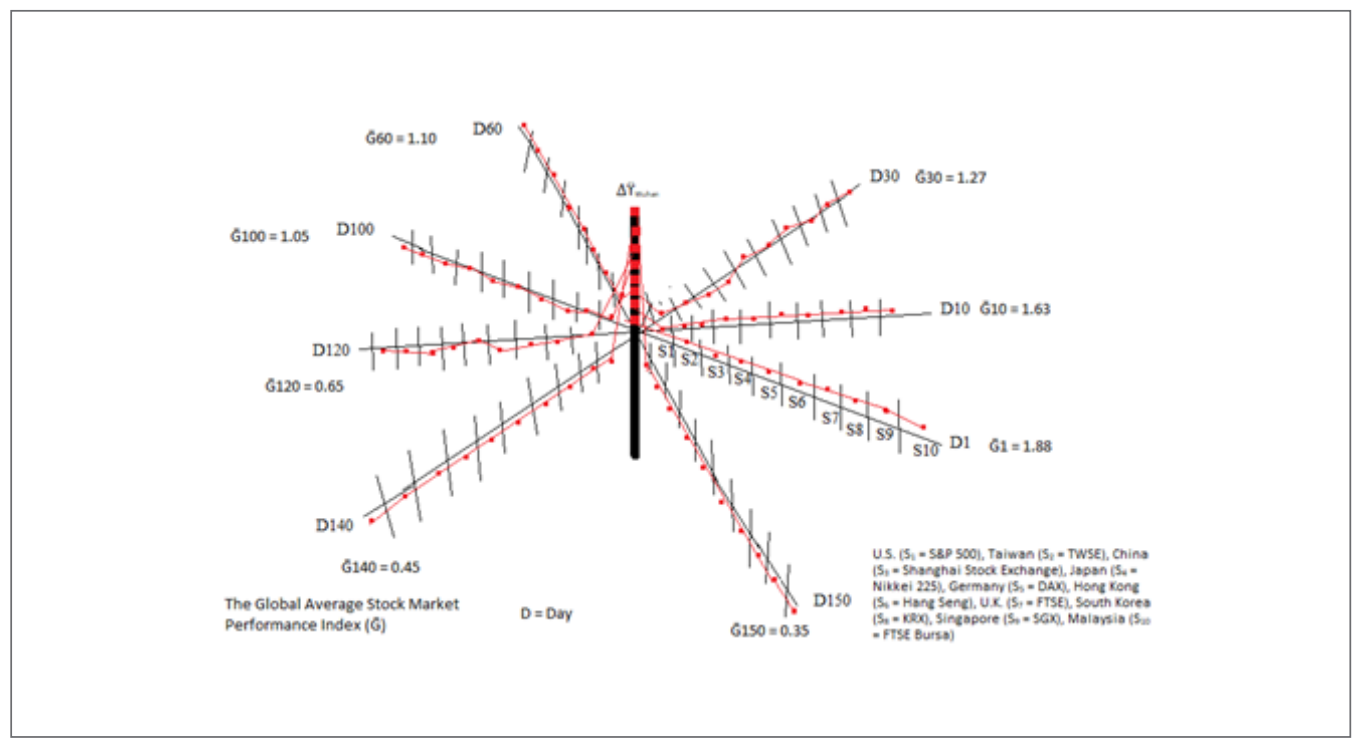

Figure 4. The $-\varphi$-Simulator final results from 10 stock markets.

Source: WHO (2020), S\&P 500 (2020), TWSE (2020), Shanghai Stock Exchange (2020), Nikkei 225 (2020), DAX (2020), Hang Seng (2020), FTSE (2020), KRX (2020), SGX (2020), FTSE Bursa (2020).

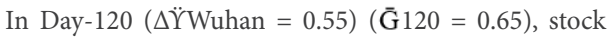
markets officially become bearish. Every economic assumption that seemed valid a month ago is now being reevaluated and revised downward. Stock prices reflect expectations of future profits, and investors see the virus dampening economic activity and reducing profits. According to $\varphi$-Simulator, it is possible to get in Day-140 optimistic estimates $(\overline{\mathrm{G}} 140=0.45, \Delta \ddot{\text { ŸWuhan }}=0.65)$, and in Day-150 pessimistic estimates $(\overline{\mathrm{G}} 150=0.35$, $\Delta \ddot{Y}$ Wuhan $=0.85)$ given the assumption that we arrive to the maximum damage of COVID-19. Suddenly the COVID-19 is under control and exist a possible vaccination worldwide.

Intuitively, the pandemic aftermath will be uncharted territory for the world economies and financial markets. It is a plausible conjecture that the world economy may experience a new economic phenomenon, so-called by authors as a stagpression. In this situation, recession overlaps depression causing structural economic deconstruction. It will present a dilemma for economic policy since expansionary actions intend to boost economic activity through monetary and fiscal stimulus would be inefficient if economies cross their sustain- ability threshold level. The structural resilience of an economy depends on its strength to absorb the impact of economic lockdown without affecting business and employment viability. If the economy crosses the sustainability level, production, consumption, and wealth will plummet; then it will be required a revitalization of the economy. Rejuvenation involves restoring the flow of goods and services within the country and across the border, through infrastructure, private sector, human capital, and financial sector development. In particular, the implementation of place-based policies will focus on rebuilding local economies, create new employment opportunities, and ensure sufficient financial assistance for the displaced, unemployed, under-employed, and new entrants. Consumer spending should restore to its default values since it constitutes 50 to 70 percent of GDP.

Empirical evidence shows that gradual unfavorable supply and demand shocks with medium- and shortterm effects in output and employment characterizes the previous episodes of financial crises. In the case of stagpression, the epidemic impact on economic activity differs in terms of magnitude and intensity: an 
economy experiences a supply and demand shocks in the short-run with instant effects in output and employment. In contrast to previous financial crises, the double impact on demand will contract imports and exports.

The disruption of global economic production due to the shutdown of China-centric global supply chains generated output shortages on intermediate and final goods. Even if the Chinese government introduces an infrastructure spending program to restore its prepandemic production capacity, this effort will not be followed by pre-pandemic demand levels. In parallel, export dependence and export concentration economies in durable goods, mining, and oil production will be severely hurt, shifting from a short-term recession to a medium and-maybe- a long-term depression by the end of 2020. In contrast, agriculture sector economies will enforce restrictions or even ban exports in an attempt to secure domestic demand first, triggering major trade disruptions in the complex food value chain: production, processing, packaging, storage, transportation, and retail sales. Domestically, tourism, transportation, entertainment, retail, and small businesses are devasted, followed by durable goods value chain. Logically, some sectors may benefit, such as ecommerce, food retail, and the healthcare industry providing at least some economic growth to offset the damage.

Consistent with the literature, a sharp decline of production will affect future capital and inflows and outflows, translating into high stock market volatility. In turn, volatility shocks affect economic activity with a further decline in investment, GDP, output, and employment. As a result, further increase liquidity constraints and credit market tightening in global financial markets, with adverse fallout effects on economic growth. The prospect of economic growth determines the behavior of the financial markets, of which is based on several factors, including the magnitude and duration of national shutdowns, the extent of reduced demand for goods and services in other parts of the economy, and the speed at which significant fiscal and monetary support takes effect. Given the current conditions, American financial markets will experience substantial capital inflows, especially from emerging Asian economies. The impact on the European financial markets seems ambiguous.

\section{Concluding Remarks}

The model provides a preliminary explanation and prediction of infectious disease behavior and adds new theoretical information about the nature of epidemics since there is always a gap between a real influence on the nature of an epidemic and a theoretical understanding of that influence. Furthermore, the paper introduces the concept of stagpression, a new economic phenomenon to explain the uncharted territory that is getting into the world economies and financial markets.

It is plausible to expect that the aftermath of COVID-19 has the potential to cause widespread economic disruption. $\Phi$-Simulator findings suggest that the 150 lockdown period can be disastrous for all economies if they cross their sustainability threshold level. The analysis of ten major stock markets worldwide shows that the effects of COVID-19 can generate similar damage to the Crisis $1929(\overline{\mathrm{G}}=0.23)$. It will require a 9-to-12-month recovery phase considering the outcome of American elections, the reconstruction measures of the European economies, and the decentralization of production from China. We can observe with the $\varphi$-Simulator possible scenarios and the final effect of any massive pandemic infectious diseases by the levels of the global average stock market performance index $(\overline{\mathrm{G}})$.

Undoubtedly, the counter-pandemic measures have had sudden and profound economic impacts. In view of the coming recession, automatic stabilizers will provide a significant economic stimulus to those who needed it. However, this is not a normal recession but rather a stagpression. In the short run, so long as confinement and lockdown constraints are on, potential output will remain much lower. Economic contraction is already on its way with irreversible repercussions to the economy. In previous recessions, trade protectionism policies, along with export subsidies, enabled businesses to recover in the medium term. However, the current pandemic constitutes the traditional policy response irrelevant. Each government has to preserve the country's productive capacity restoring consumer spending, business investment, and market expectations.

Further and coordinated action is required from all governments to support economic activity directly. Employment has to be recovered close to prere- 
cession levels. Conventional monetary policy action aimed to lower borrowing costs for individuals and businesses, thereby encouraging both immediate consumption and investment. This policy will not be effective since the economy's sustainability threshold level is crossed. Pandemic has already generated an economically unacceptable environment characterized by business bankruptcies, foreclosures/evictions, and forbearance on debt. Government intervention is imperative to correct the economy's failures and promote the general welfare of the society.

$\Phi$-Simulator offers to policymakers, central banks, academics, and students an alternative multi-dimensional graphical modeling approach to analyze the pandemic impact on capital markets from a multidimensional perspective. The multi-dimensional approach to financial market analysis presented in this study needs to be explored further to realize its full potential. The classic two-dimensional Euclidean configuration carries mathematical and graphical limitations that fail to capture all possible financial market equilibria. It is, therefore, necessary to continue the empirical validation exercises by considering professional subjects, designing new experiments with more cases and different algorithms, running case studies with real data from the economic environment to ensure conclusion validity.

\section{References}

Abbara, O., \& Zevallos, M. (2014). Assessing stock market dependence and contagion. Quantitative Finance, 14(9), 1627-1641. https://doi.org/10.108 $0 / 14697688.2013 .859390$

Arghyrou, M. G., \& Kontonikas, A. (2012). The EMU soveireign-debt crisis: fundamentals, expectations and contagion. Journal of International Financial Markets, Institutions and Money, 22(4), 658-677. https://doi.org/10.1016/j.intfin.2012.03.003

Bannier, C. E. (2006). The role of information fisclosure and uncertainty in the 1994/95 Mexican Peso Crisis: Empirical evidence. Review of International Economics, 14(5), 883-909. https:// doi.org/10.1111/j.1467-9396.2006.00596.x

Bekiros, S. D. (2014). Contagion, decoupling and the spillover effects of the US financial crisis: Evidence from the BRIC markets. International Review of Financial Analysis, 33(May), 58-69. https://doi. org/10.1016/j.irfa.2013.07.007
Billio, M., \& Pelizzon, L. (2003). Contagion, and interdependence in stock markets: Have they been misdiagnosed? Journal of Economics and Business, 55(5), 405-426. https://doi.org/10.1016/S01486195(03)00048-1

Bodart, V., \& Candelon, B. (2009). Evidence of interdependence and contagion using a frequency domain framework. Emerging Markets Review, 10(2), 140-150. https://doi.org/10.1016/j. ememar.2008.11.003

Calvo, S. G., \& Reinhart, C. M. (1996). Capital flows to Latin America: Is there evidence of contagion effects? World Bank Policy Research Working Papers (No. 1619). World bank. https://doi. org/10.2139/ssrn.1815938

Candeias, V., \& Morhard, R. (2018). The human costs of epidemics are going down but the economic costs are going up. Here's why. World Economic Forum. https://www.weforum.org/agenda/2018/05/howepidemics-infect-the-global-economy-and-whatto-do-about-it/

Caporin, M., Pelizzon, L., Ravazzolo, F., \& Rigobon, R. (2018). Measuring sovereign contagion in Europe. Journal of Financial Stability, 34 (February), 150181. https://doi.org/10.1016/j.jfs.2017.12.004

Centers for Disease Control and Prevention. (2020). Ebola (Ebola Virus Disease). https://www.cdc. gov/vhf/ebola/history/2014-2016-outbreak/costof-ebola.html

Chang, R., \& Majnoni, G. (2002). Fundamentals, beliefs, and financial contagion. European Economic Review, 46(2002), 801-808. https://doi. org/10.1016/S0014-2921(01)00214-8

Cheng, E. (2020). 'Not unreasonable' for China's economy to shrink $10 \%$ in the first quarter, independent survey shows. https://www. cnbc.com/2020/03/24/china-beige-bookq1-contraction-in-chinas-economy-fromcoronavirus.html

Chira, I., \& Marciniak, M. (2014). Risk change during crises: how do purely local companies differ from cross-listed firms? Evidence from the European crisis of 2010-2012. Journal of Economics and Business, 74(July-August), 11-23. https://doi. org/10.1016/j.jeconbus.2014.03.001

Cho, J. H., \& Parhizgari, A. M. (2008). East Asian financial contagion under DCC-GARCH. International Journal of Banking and Finance, 6(1), 17-30. https://doi.org/10.32890/ijbf2009.6.1.8380

Constancio, V. (2012). Contagion and the European debt crisis. Financial Stability Review, 16(April), 190-119. 
DAX. (2020). Secondary Dataset. https://www.daxindices.com/

Day, M. (2020). COVID-19: identifying and isolating asymptomatic people helped eliminate virus in Italian village. BMJ. https://doi.org/10.1136/bmj. m1165

DeCambre, M. (2020). How the stock market has performed during past viral outbreaks, as coronavirus spreads to Italy and Iran. Market Watch. https://www.marketwatch.com/story/hereshow-the-stock-market-has-performed-duringpast-viral-outbreaks-as-chinas-coronavirusspreads-2020-01-22

Dimitriou, D., \& Simos, T. (2013). Contagion channels of the USA subprime financial crisis: Evidence from USA, EMU, China and Japan equity markets. Journal of Financial Economic Policy, 5(1), 61-71. https://doi.org/10.1108/17576381311317781

Dooley, M., \& Hutchison, M. (2009). Transmission of the US subprime crisis to emerging markets: evidence on the decoupling-recoupling hypothesis. Journal of International Money and Finance, 28(8), 1331-1349. https://doi. org/10.1016/j.jimonfin.2009.08.004

Dorra, Z., \& Achraf, G. (2014). Herding behavior contagion in Tunisian financial system during the revolution period. IUP Journal of Bank Management, 13(4), 20-36.

Eichengreen, B., Rose, A. K., \& Wyplosz, C. (1994). Speculative attacks on pegged exchange rates: an empirical exploration with special reference to the European Monetary System(NBER Working Papers 4898). National Bureau of Economic Research, Inc. https://www.nber.org/papers/w4898

Flavin, T. J., \& Sheeman, L. (2015). The role of US subprime mortgage-backed assets in propagating the crisis: Contagion or interdependence? The North American Journal of Economics and Finance, 34(November), 167-186. https://doi.org/10.1016/j. najef.2015.09.001

Fry-McKibbin, R., \& Hsiao, C. Y.-L. (2015). Extremal dependence tests for contagion. CAMA Working Papers 2015-40. Centre for Applied Macroeconomic Analysis, Crawford School of Public Policy, The Australian National University.

FTSE. (2020). Secondary Dataset.

FTSE Bursa. (2020). Secondary Dataset. Retrieved from: https://www.bursamalaysia.com/

Glover, B., \& Richards-Shubik, S. (2014). Contagion in the European sovereign debt crisis(NBER Working Papers 20567). National Bureau of Economic Research. https://doi.org/10.3386/w20567
Gomez-Puig, M., \& Sosvilla-Rivero, S. (2016). Causes and hazards of the euro area sovereign debt crisis: Pure and fundamentals-based contagion. Economic Modelling, 56(August), 133-147. https://doi.org/10.1016/j. econmod.2016.03.017

Guo, F., Chen, C. R., \& Huang, Y. S. (2011). Markets contagion during financial crisis: A regimeswitching approach. International Review of Economics \& Finance, 20(1), 95-109. https:// doi.org/10.1016/j.iref.2010.07.009

Hang Seng. (2020). Secondary Dataset. Retrieved from: https://www.hkex.com.hk/?sc_lang=en

He, C. (2020). Coronavirus: the blow to the Chinese economy could be felt for years. The Conversation. http://theconversation. com/coronavirus-the-blow-to-the-chineseeconomy-could-be-felt-for-years- 131793

He, L. (2020). Coronavirus devastates China's economy and the 'nightmare' is not over. CNN Business. Retrieved from https://www.cnn. com/2020/03/16/economy/china-economycoronavirus/index.html

Hoesli, M., \& Reka, K. (2013). Volatility spillovers, co-movements and contagion in securitized real estate markets. The Journal of Real Estate Finance and Economics, 47(1), 1-35. https:// doi.org/10.1007/s11146-011-9346-8

Hsiao, C. Y.-L., \& Morley, J. (2015). Debt and financial market contagion (UNSW Business School Research Paper No. 2015-02). University of New South Wales. https:// papers.ssrn.com/sol3/papers.cfm?abstract_ id $=2562121$

Islam, R. (2014). A comparison of the long term interdependence of Southeast Asian equity markets. Journal of East Asian Economic Integration, 18(2), 187-212.

Ito, T., \& Hashomoto, Y. (2005). High-frequency contagion of currency crises in Asia. Asian Economic Journal, 19(4), 357-381. https://doi. org/10.1111/j.1467-8381.2005.00217.x

Jayech, S. (2016). The contagion channels of JulyAugust-2011 stock market crash: A DAGcopula based approach. European Journal of Operational Research, 249(2), 631-646. https:// doi.org/10.1016/j.ejor.2015.08.061

Johnson, K., \& Palmer, J. (2020). Knock-on effects of China's coronavirus may be worse than thought. Foreign Policy. https://foreignpolicy. com/2020/02/03/knock-on-effects-chinacoronavirus-weak-economy-markets/ 
Joo, H., Maskery, B. A., Berro, A. D., Rotz, L. D., Lee, Y. K., \& Brown, C. M. (2019). Economic impact of the 2015 MERS outbreak on the Republic of Korea's tourism-related industries. Health Security, 17(2), 100-108. https://doi.org/10.1089/ hs. 2018.0115

Kalish, I. (2020). Weekly global economic update. Deloitte Insights. https://www2.deloitte.com/us/ en/insights/economy/global-economic-outlook/ weekly-update.html

Karabell, Z. (2020). A stock market crash was coming, coronavirus was just the spark. TIME. https://time. com/5793506/a-stock-market-crash-was-comingcoronavirus-was-just-the-spark/

Karlgaard, R. (2020). Economic forecasting in the age of coronavirus - 3 Tips. Forbes. https://www. forbes.com/sites/richkarlgaard/2020/03/29/ economic-forecasting-in-the-age-of-coronavirus--3-tips/\#39cc5b546e78

Kenourgios, D., \& Dimitriou, D. (2015). Contagion of the global financial crisis and the real economy: a regional analysis. Economic Modelling, 44(January), 283-293. https://doi.org/10.1016/j. econmod.2014.10.048

Kilic, B. H., \& Ulusoy, V. (2015). Evidence for financial contagion in endogenous volatile periods. Review of Development Economics, 19(1), 62-74. https://doi. org/10.1111/rode.12126

Kim, B. H., Kim, H., \& Lee, B. S. (2015). Spillover effects of the US financial crisis on financial markets in emerging Asian countries. International Review of Economics \& Finance, 39(September), 192-210. https://doi.org/10.1016/j.iref.2015.04.005

Kimball, A., Hatfield, K. M., Arons, M., James, A., Taylor, J., Spicer, K., \& Bardossy, A. C. (2020). Asymptomatic and presymptomatic SARS-CoV-2 infections in residents of a long-term care skilled nursing facility - King County, Washington, March 2020. Morbidity and Mortality Weekly Report, 69(13), 377-381 https://doi.org/10.15585/mmwr. $\mathrm{mm} 6913 \mathrm{e} 1$

Kondratieff, N. D. (1922). The World Economy And Its Conjunctures During and After The War. Regional Branch of the State Publishing House.

KRX. (2020). Secondary Database. http://global.krx. co.kr/main/main.jsp

Lauer, S. A., Grantz, K. H., Bi, Q., Jones, F. K., Zheng, Q., Meredith, H. R., ... \& Lessler, J. (2020). The incubation period of coronavirus disease 2019 (COVID-19) from publicly reported confirmed cases: estimation and application. Annals of Internal Medicine, 172(9), 577-582. https://doi.org/10.7326/M20-0504
Liang, M., Yang, Y., Youliang, Q., \& Yan, Y. (2012). Annual economic impacts of seasonal influenza on US counties: Spatial heterogeneity and patterns. International Journal of Health Geographics, 11(1), 16. https://doi.org/10.1186/1476-072X-11-16.

Lloyd, C. (2020). Epidemics, economic growth And stock-market performance - A historical perspective. SeekingAlpha. https://seekingalpha. com/article/4331798-epidemics-economicgrowth-and-stock-market-performancehistorical-perspective

Luchtenberg, K. F., \& Vu, Q. V. (2015). The 2008 financial crisis: stock market contagion and its determinants. Research in International Business and Finance, 33(January), 178-203. https://doi. org/10.1016/j.ribaf.2014.09.007

Mighri, Z., \& Mansouri, F. (2014). Modeling international stock market contagion using multivariate fractionally integrated APARCH approach. Cogent Economics and Finance, 2(1), 1-25. https://doi.org/10.1080/23322039.2014.96 3632

Mink, M., \& De Haan, J. (2013). Contagion during the Greeksovereign debt crisis. Journal of International Money and Finance, 34(April), 102-113. https:// doi.org/10.1016/j.jimonfin.2012.11.006

Mizumoto, K., Kagaya, K., Zarebski, A., \& Chowell, G. (2020). Estimating the asymptomatic proportion of coronavirus disease 2019 (COVID-19) cases on board the Diamond Princess cruise ship, Yokohama, Japan, 2020 separator. Eurosurveillance, 25(10). https://doi. org/10.2807/1560-7917.ES.2020.25.10.2000180

Mollah, S., Quoreshi, A. S., \& Zafirov, G. (2016). Equity market contagion during global financial and Eurozone crises: Evidence from a dynamic correlation analysis. Journal of International Financial Markets, Institutions and Money, 41(March), 151-167. https://doi.org/10.1016/j. intfin.2015.12.010

Mondria, J., \& C., Q.-D. (2013). Financial contagion and attention allocation. The Economic Journal, 123(568), 429-454. https://doi.org/10.1111/ j.1468-0297.2012.02530.x

Nikkei 225. (2020). Secondary Database. Retrieved from: https://indexes.nikkei.co.jp/en/nkave/

Nishiura, H., Kobayashi, T., Suzuki, A., Jung, S.M., Hayashi, K., Kinoshita, R., . . Miyama, T. (2020). Estimation of the asymptomatic ratio of novel coronavirus infections (COVID-19). International Journal of Infectious Diseases 94,154.. https://doi.org/10.1016/j.ijid.2020.03.020 
Pan, Z., Zheng, X., \& Gong, Y. (2015). A model-free test for contagion between crude oil and stock markets. Economic Letters, 130(May), 1-4. https:// doi.org/10.1016/j.econlet.2015.02.023

Pankratyeva, A. (2020). Top three reasons behind the stock market crash 2020: is it coronavirus, oil price war or vanished liquidity? Capital.com. https://capital.com/stock-market-crash-2020

Ramelli, S., \& Wagner, A. (2020). What the stock market tells us about the consequences of COVID-19. VOX CEPR Policy Portal. https:// voxeu.org/article/what-stock-market-tells-usabout-consequences-COVID-19

Rigobon, R. (2003). On the measurement of the international propagation of shocks: Is the transmission stable? Journal of International Economics, 61(2), 261-283. https://doi. org/10.1016/S0022-1996(03)00007-2

Rotta, P. N., \& Pereira, P. L. V. (2015). Analysis of contagion from the dynamic conditional correlation model with Markov Regime switching. Applied Economics, 48(25), 2367-2382. https://doi. org/10.1080/00036846.2015.1119794

Roy, R. P., \& Roy, S. S. (2015). Financial contagion and volatility spillover: An exploration into Indian commodity derivative market. Economic Modelling, 67(December), 368-380. https://doi. org/10.1016/j.econmod.2017.02.019

Ruiz Estrada, M. A. (2009a). Economic modeling in real time(FEA - Working Paper No. 2009-11). Faculty of Economics and Administration, University of Malaya.

Ruiz Estrada, M. A. (2009b). Multi-dimensional economic modeling(FEA - Working Paper No. 2009-7). Faculty of Economics and Administration, University of Malaya.

Ruiz Estrada, M. A. (2011). Multi-dimensional coordinate spaces. International Journal of the Physical Sciences, 6(3), 340-357.

Ruiz Estrada, M. A. (2013). The global economic crisis smash effect simulator (GECSE0Simulator). International Journal of Economic Research, 10(2), 269-275.

Ruiz Estrada, M. A. (2017). An alternative graphical modeling for economics: Econographicology Quality \& Quantity, 51(5), 2215-2139. https://doi. org/10.1007/s11135-015-0280-3

Ruiz Estrada, M. A., Chandran, V., \& Tahir, M. (2016). An introduction to multidimensional real-time economic modeling. Journal of Contemporary Economics, 10(1), 55-70. https://doi.org/10.2139/ ssrn. 2282926
Ruiz Estrada, M. A., \& Koutronas, E. (2020). The Application of the 2019-nCoV Global Economic Impact Simulator (the 2019-nCoV-GEISimulator) in China. SSRN. https://doi.org/1doi. org/10.2139/ssrn.3542817

Ruiz Estrada, M. A., \& Yap, S. F. (2013). The origins and evolution of policy modeling. Journal of Policy Modeling, 35(1), 170-182. https://doi. org/10.1016/j.jpolmod.2011.12.003

S\&P 500. (2020). Secondary Database. https://www. standardandpoors.com/en_US/web/guest/ home

Saleem, K. (2009). International linkage of the Russian market and the Russian financial crisis: a multivariate GARCH analysis. Research in International Business and Finance, 23(3), 243256. https://doi.org/10.1016/j.ribaf.2008.09.003

Samarakoon, L. P. (2011). Stock market interdependence, contagion, and the US financial crisis: The case of emerging and frontier markets. Journal of International Financial Markets, Institutions and Money, 31(5), 724-742. https://doi.org/10.1016/j.intfin.2011.05.001

Schumpeter, J. A. (1954). History of Economic Analysis. George Allen \& Unwin.

Seth, N., \& Panda, L. (2018). Financial contagion: Review of empirical literature. Qualitative Research in Financial Markets, 10(1), 15-70. https://doi.org/10.1108/QRFM-06-2017-0056

SGX. (2020). Secondary Database. Retrieved from: https://www.sgx.com/

Shanghai Stock Exchange. (2020). Secondary Database. Retrieved from: http://english.sse. com.cn/

Shepard, D. S., Undurraga, E., Halasa, Y., \& Stanaway, J. D. (2016). The global economic burden of dengue: A systematic analysis. Lancet Infect, 16(8), 935-941. https://doi.org/10.1016/S14733099(16)00146-8

Sherman, E. (2020). 5 reasons coronavirus statistics seem inconsistent. Fortune. https://fortune. com/2020/02/24/coronavirus-statistics-whodata-transparency/

Sojli, E. (2007). Contagion in emerging markets: The Russian crisis. Applied Financial Economics, 17(3), 197-213. https://doi. org/10.1080/09603100600639876

Song, H., Xiao, J., Yin, J., Yang, H., Shi, R., \& Zhang, W. (2020). A considerable proportion of individuals with asymptomatic SARS-CoV-2 infection in Tibetan population. MedRxiv. https://doi.org/10.1101/2020.03.27.20043836 
Steinherr, A. (2006). Russian banking since the crisis of 1998. Economic Change and Restructuring, 39(3-4), 235-259.

Tabak, B. M., de Castro Miranda, R., \& da Silva Medeiros, M. (2016). Contagion in CDS, banking and equity markets. Economic Systems, 40(1), 120134. https://doi.org/10.1016/j. ecosys.2015.07.002

Taleb, N. N. (2007). The Black Swan: The Impact of the Highly Improbable. Random House, Inc.

TWSE. (2020). Secondary Database. https://www. twse.com.tw/en/

United Nations. (2017). A socio-economic impact assessment of the Zica Virus in Latin America and the Caribbean. Retrieved from https://www. undp.org/content/undp/en/home/librarypage/ hiv-aids/a-socio-economic-impact-assessmentof-the-zika-virus-in-latin-am.html

Wanwan, S., Feng, L., Jinren, P., Jian, C., Ziping, M., helan, L., . . . Enfu, C. (2020). Epidemiological characteristics of 2019 novel coronavirus family clustering in Zhejiang Province. Chinese Journal of Preventive Medicine, 54(6), 625-629. https://doi. org/10.3760/cma.j.cn112150-20200227-00199

World Health Organization. (2020). COVID-2019 Situation Reports. https://www.who.int/ emergencies/diseases/novel-coronavirus-2019/ situation-reports/

Wu, C., Chen, C.-n., \& He, Y. (2003). The performance of East Asian economies and financial markets since the 1997 financial crisis. Review of Pacific Basin Financial Markets and Policies, 6(2), 113-140. https://doi.org/10.1142/ S021909150300102X

$\mathrm{Wu}, \mathrm{W}$. (2020). China to inject US\$174 billion of liquidity into markets amid new coronavirus outbreak. South China Morning Post. https:// www.scmp.com/economy/china-economy/ article/3048618/china-inject-us 174-billionliquidity-markets-amid-new

Xie, J. (2020). In China, officials exclude asymptomatic COVID-19 carriers from data. Voice of America (VOA). https://www.voanews. com/science-health/coronavirus-outbreak/ china-officials-exclude-asymptomatic-COVID19-carriers-data

Yiu, M.S., AlexHo, W. Y., \& Choi, D. F. (2010). Dynamic correlation analysis of financial contagion in Asian markets in global financial turmoil. Applied Financial Economics, 20(4), 345-354. https://doi.org/10.1080/09603100903494946

\section{Endnotes}

1. Many experts have argued that it is an 'accelerant' rather than the sole core reason behind the crash (Karabell, 2020; Pankratyeva, 2020).

2. Econographicology revolves around the efficacy of multi-dimensional graphs in the storage of meta-database and the visualization of multi-variable data behavior based on the application of Cartesian coordinate space.

3. Dynamic Imbalance state assumption incorporates internalities and externalities in the explanation of market behavior.

4. Omnia Mobilis assumption suggests the simultaneous observation of changes in all variables in real-time. This assumption allows a large number of variables to be simultaneously observed in a multi-dimensional analysis, as opposed to the ceteris paribus assumption, which keeps variables constant.

5. A fundamentals-driven crisis is more contagious than a beliefs-driven crisis, and is more contagious than when information is less complete (Chang \& Majnoni, 2002).

\section{Erratum:}

Due to an editing error, the acceptance date of the paper and the affiliation of one of the authors (Mario Arturo Ruiz Estrada) were inaccurate. Hence, the following erratum was added to signal that fact, and the missing data was supplemented. The changes included:

1. Incorrect acceptance date: changed from 12.10.2020 to 12.12.2020,

2. Missing affiliation of Mario Arturo Ruiz Estrada: The University of Economics and Human Sciences in Warsaw. 